\title{
ЕФЕКТИВНІСТЬ ЗАСТОСУВАННЯ ЕНТЕРОСОРБЦІЙНОї ТЕРАПІЇ В КОМПЛЕКСНОМУ ЛІКУВАННІ ХВОРИХ НА ХРОНІЧНЕ ОБСТРУКТИВНЕ ЗАХВОРЮВАННЯ ЛЕГЕНЬ ЗРІЛОГО I СЕРЕДНЬОГО ВІКУ З ЛАБОРАТОРНИМИ ПРОЯВАМИ ЕНДОГЕННОї ІНТОКСИКАЦІї
}

\author{
○С. М. Андрейчин, С. В. Кучер, І. І. Ганьбергер, Н. А. Кавецька, М. М. Руда
}

ДВНЗ «Тернопільський державний медичний університет імені І. Я. Горбачевського МОЗ України»

РЕзюМЕ. Наведено результати дослідження показників синдрому ендогенної інтоксикації у хворих на ХОЗЛ зрілого і середнього віку при включенні в комплексну терапію захворювання ентеросорбентів ентеросгель або карболайн. Відзначено позитивний вплив ентеросорбції на фоні базисної терапії хворих на ХОЗЛ, про що свідчать зменшення рівня молекул середньої маси та нормалізація еритроцитарного індексу інтоксикації.

КЛючОВІ СлОВА: ХОЗЛ; ентеросгель; карболайн; синдром ендогенної інтоксикації.

Вступ. Ендогенна інтоксикація (EI) - це синдром, характерний для багатьох патологічних процесів та захворювань. Він розвивається при накопиченні в організмі ендотоксинів різного походження та складу, які впливають на структуру клітин, тканин та органів пацієнтів як безпосередньо, так і опосередковано, викликаючи деструкцію білків і ліпідів клітин, блокуючи синтетичні й окисні процеси. Спостерігається синдром ендогенної інтоксикації (CEI) і при хронічному обструктивному захворюванні легень (ХОЗЛ) [1].

Актуальність проблеми ХОЗЛ зумовлена невпинним зростанням кількості хворих з цією патологією. Це захворювання другої половини життя, зазвичай виникає після 45 років, досягаючи найбільшої вираженості до 60 років. Раціональне лікування цих пацієнтів має цілий ряд особливостей, які викликані віковими морфофункціональними змінами бронхолегеневої системи, наявністю супутньої (позалегеневої) патології і частою її декомпенсацією на тлі загострень ХОЗЛ, атиповим перебігом загострень, частою наявністю дихальної недостатності тощо [2].

Усе наведене обґрунтовує доцільність поглибленого дослідження СЕІ у хворих на ХОЗЛ зрілого і середнього віку, а також застосування терапії, спрямованої на дезінтоксикацію організму за допомогою ентеросорбентів з високою поглинальною здатністю.

Мета дослідження - з'ясувати ефективність ентеросорбційної терапії у комплексному лікуванні хворих на ХОЗЛ зрілого і середнього віку у фазі загострення шляхом дослідження змін лабораторних показників ЕІ у сироватці крові.

Матеріал і методи дослідження. Під спостереженням було 90 хворих на ХОЗЛ у фазі загострення зрілого і середнього віку (від 40 до 59 років). Серед них було 60 чоловіків $(66,7 \%)$ і 30 жінок (33,3 \%). Середній вік обстежуваних становив $(51,02 \pm 0,63)$ років. Діагноз ХОЗЛ встановлювали на основі уніфікованих діагностичних критеріїв згідно з Наказом МОЗ України від 27.06.2013 № 555 [3].

ХОЗЛ діагностували на основі клінічних симптомів, даних анамнезу, фізикального обстеження й спірометрії.

Згідно з лікуванням, яке отримували пацієнти, всі вони були поділені на 3 групи. 30 пацієнтів одержували лише базисну терапію (БТ) згідно з діючим наказом МО3 України № 555. Серед них було 6 осіб зрілого віку та 24 - середнього. Ще 30 осіб, окрім БТ, додатково отримували кремнійорганічний ентеросорбент ентеросгель у вигляді гелю перорально по 1 столовій ложці протягом 10 днів 3 рази на день за 2 години до або через 2 години після приймання їжі та медикаментозних засобів. Серед них було 8 осіб зрілого віку та 22 - середнього. Наступні 30 пацієнтів, крім БТ, додатково отримували вуглецевий ентеросорбент IV покоління карболайн у вигляді дрібних гранул перорально по 1 чайній ложці протягом 10 днів 3 рази на день за 2 години до або через 2 години після приймання їжі та медикаментозних засобів. Серед цих обстежених було 9 осіб зрілого віку та 21 - середнього.

Для виявлення El у пацієнтів визначали рівень молекул середньої маси $\left(\mathrm{MCM}_{254}\right.$ та $\left.\mathrm{MCM}_{280}\right)$ у сироватці крові за методом Н. І. Габріеляна і співавторів [4]. Еритроцитарний індекс інтоксикації (EII) визначали за методикою, описаною А. А. Тогайбаєвим [5].

Обробка результатів виконана у відділі системних статистичних досліджень ДВНЗ «Тернопільський державний медичний університет імені І. Я. Горбачевського МОЗ України» в програмному пакеті Statsoft STATISTICA [5].

Результати й обговорення. Результати наших спостережень свідчать, що застосування БТ покращило стан пацієнтів і зменшило рівень інтоксикації у всіх групах різного віку, про що свідчило зменшення рівня показників Еl.

Так, вміст MCM $_{254}$ і MCM $_{280}$ у сироватці крові пацієнтів після застосування БТ зменшився на 
Огляди літератури, оригінальні дослідження, погляд на проблему

$8,5 \%$ ( $p>0,05)$ і 19,7 \% ( $p<0,01)$ відповідно, порівняно з вихідним рівнем, а Ell - на 19,5\% ( $<<0,001)$. При порівнянні отриманих показників після застосування БТ з контрольною групою не виявлено їх нормалізації ( $p<0,001)$.

Приєднання до БТ ентеросорбенту ентеросгель привело до ще більшого зменшення показників ендотоксикозу, про що свідчить зменшення вмісту MCM та Ell. Вміст MCM $_{254}$ у пацієнтів зменшився на $14,8 \%(p<0,05)$, MCM $_{280}$ - на $24,4 \%$ ( $p<0,001)$, Ell - на 25,0 \% (p<0,001). При порівнянні отриманих результатів з контрольними можна відмітити, що спостерігалося недостовірне зменшення різниці між ними.

Приєднання ентеросорбента карболайн до БТ привело до значного зменшення показників ЕІ у хворих на ХОЗЛ. Так, вміст МСM $_{254}$ в сироватці крові пацієнтів зменшився на 19,0\% ( $<<0,01)$, $\mathrm{MCM}_{280}$ - на 29,1\%, ElI - на 30,4 \% (р<0,001). При порівнянні отриманих результатів з контрольними можна відмітити нормалізацію рівня MCM $_{254}$ (табл. 1).

Таблиця 1. Порівняння показників ендогенної інтоксикації у сироватці крові хворих на ХОзЛ зрілого і середнього віку до та після лікування $(\mathrm{M} \pm \mathrm{m})$

\begin{tabular}{|l|c|c|c|c|c|}
\hline \multicolumn{1}{|c|}{ Показник } & $\begin{array}{c}\text { Контрольна } \\
\text { група, } \\
(\mathrm{n}=20)\end{array}$ & $\begin{array}{c}\text { До лікування } \\
(\mathrm{n}=90)\end{array}$ & $\begin{array}{c}\text { Після лікування } \\
\text { БТ }(\mathrm{n}=30)\end{array}$ & $\begin{array}{c}\text { Після лікування } \\
\text { БТ + ентеросгель } \\
(\mathrm{n}=30)\end{array}$ & $\begin{array}{c}\text { Після лікування } \\
\text { БТ+карболайн } \\
(\mathrm{n}=30)\end{array}$ \\
\hline $\begin{array}{l}\mathrm{MCM}_{254^{\prime}} \\
\text { ум. од. }\end{array}$ & $334,2 \pm 25,3$ & $499,2 \pm 17,1^{*}$ & $\begin{array}{c}456,6 \pm 19,9 * \\
\mathrm{p}>0,05\end{array}$ & $\begin{array}{c}425,1 \pm 22,8^{*} \\
\mathrm{p}<0,05\end{array}$ & $\begin{array}{c}404,1 \pm 21,0 \\
\mathrm{p}<0,01\end{array}$ \\
\hline $\begin{array}{l}\text { MCM } 280^{\prime} \\
\text { ум. од. }\end{array}$ & $149,4 \pm 13,3$ & $276,2 \pm 10,3^{*}$ & $\begin{array}{c}221,7 \pm 12,3^{*} \\
\mathrm{p}<0,01\end{array}$ & $\begin{array}{c}208,9 \pm 11,9 * \\
\mathrm{p}<0,001\end{array}$ & $\begin{array}{c}195,7 \pm 12,1^{*} \\
\mathrm{p}<0,001\end{array}$ \\
\hline $\begin{array}{l}\text { Ell, } \\
\%\end{array}$ & $33,7 \pm 3,4$ & $58,3 \pm 1,6^{*}$ & $\begin{array}{c}47,0 \pm 2,0 * \\
\mathrm{p}<0,001\end{array}$ & $\begin{array}{c}43,7 \pm 2,7^{*} \\
\mathrm{p}<0,001\end{array}$ & $\begin{array}{l}40,6 \pm 2,8 \\
\mathrm{p}<0,001\end{array}$ \\
\hline
\end{tabular}

Примітки: 1. * - вірогідність відмінностей стосовно контрольної групи (р<0,05-0,001);

2. p - вірогідність відмінностей між дослідними групами до та після лікування.

Висновки. 1. ХОЗЛ у фазі загострення супроводжується лабораторними проявами ендотоксикозу, що проявляється достовірним збільшенням вмісту показників ендогенної інтоксикації та еритроцитарного індексу інтоксикації в сироватці крові.

2. Застосування в комплексному лікуванні хворих на ХОЗЛ у фазі загострення 10-добового курсу ентеросорбційної терапії з використанням вуглецевого чи кремнійорганічного ентеросорбенту супроводжується достовірним зменшенням лабораторних проявів ендотоксикозу, таких як $\mathrm{MCM}_{254}, \mathrm{MCM}_{280}$, та еритроцитарного індексу інтоксикації.

\section{ЛІТЕРАТУРА}

1. Лотоцька С. В. Ефективність застосування ентеросорбенту «Ентеросгель» при лікуванні хворих на хронічне обструктивне захворювання легень / С. В. Лотоцька, С. М. Андрейчин, В. М. Мерецький // Вісник наукових досліджень. - 2015. - № 3. - С. 31-33.

2. Network medicine, multimorbidity and the lung in the elderly / R. Faner, T. Cruz, A. López-Giraldo, A. Agustí // European Respiratory Journal. - 2014. - Vol. 44. - P. 775-788.

3. Уніфікований клінічний протокол первинної, вторинної (спеціалізованої), третинної (високоспеціалізованої) медичної допомоги та медичної реабілітації «Хронічне обструктивне захворювання легень» Наказ МО3 України від 27.06.2013 р. №555. [Електронний ре-

сурс]. - Режим доступу : http://mtd.dec.gov.ua/images/ dodatki/2013_555_HOZL/2013_555hozl_ykpmd.pdf.

4. Габриэлян Н. И. Скрининговый метод определения средних молекул в биологических жидкостях : методические рекомендации / Н. И. Габриэлян, Э. Р. Левицкий, А. А. Дмитриев. - М. : Изд-во Московск. ун-та, 1985. -35 с.

5. Тогайбаев А. А. Определение эритроцитарного индекса / А. А. Тогайбаев, И. В. Кургузкин, И. В. Ракун // Лабораторное дело. - 1988. - № 9. - С. 22-24.

6. Реброва О. Ю. Статистический анализ медицинских данных. Применение пакета программ Statistica / О. Ю. Реброва. - М. : МедиаСфера, 2006. - 31 с. 
Огляди літератури, оригінальні дослідження, погляд на проблему

\section{REFERENCES}

1. Lototska, S.V., Andreichyn, S.M. \& Meretskyi, V.M. (2015). Efektyvnist zastosuvannia enterosorbentu "Enteroshel" pry likuvanni khvorykh na khronichne obstruktyvne zakhvoriuvannia lehen [Effectiveness of the usage of chelator "Enterosgel" in treating patients with chronic obstructive pulmonary disease]. Visnyk naukovykh doslidzhen - Bulletin of Scientific Researches, 3, 31-33 [in Ukrainian].

2. Faner, R., Cruz, T., López-Giraldo, A., \& Agustí, A. (2014). Network medicine, multimorbidity and the lung in the elderly. European Respiratory Journal, 44, 775-788.

3. Unifikovanyi klinichnyi protokol pervynnoi, vtorynnoi (spetsializovanoi), tretynnoi (vysokospetsializovanoi) medychnoi dopomohy ta medychnoi reabilitatsii. Khronichne obstruktyvne zakhvoriuvannia lehen [Unified clinical protocols of primary, secondary (specialized), third (highly specialized) care and rehabilitation. Chronic ob- structive pulmonary disease]. Nakaz MOZ Ukrainy vid 27.06.2013 № 555 [in Ukrainian].

4. Gabrielyan, N.I., Levitskyy, E.R. \& Dmitriev, A.A (1985). Skriningovyy metod opredeleniya srednikh molekul v biologicheskikh zhidkostyah: metodicheskie rekomendatsii [Screening method for determining average molecules in biological fluids: methodological recommendations]. Moscow: MSU Publishing House.

5. Togaybaev, A.A., Kurguzkin, I.V., \& Rakun, I.V. (1988). Opredelenie yeritrotsitarnogo indeksa [Definition of erythrocyte index]. Laboratornoe delo - Laboratory Work, 9, 22-24.

6. Rebrova, O.Yu. (2006). Statisticheskiy analiz meditsinskih dannykh. Primenenie paketa programm Statistika [Statistical analysis of medical data. Application of the Statistica software package]. Moscow. MediaSphere.

\title{
ЭФФЕКТИВНОСТЬ ПРИМЕНЕНИЯ ЭНТЕРОСОРБЦИОННОЙ ТЕРАПИИ В КОМПЛЕКСНОМ ЛЕЧЕНИИ БОЛЬНЫХ ХРОНИЧЕСКИМ ОБСТРУКТИВНЫМ ЗАБОЛЕВАНИЕМ ЛЕГКИХ ЗРЕЛОГО И СРЕДНЕГО ВОЗРАСТА С ЛАБОРАТОРНЫМИ ПРОЯВЛЕНИЯМИ ЭНДОГЕННОЙ ИНТОКСИКАЦИИ
}

\author{
๑С. М. Андрейчин, С. В. Кучер, И. И. Ганьбергер, Н. А. Кавецкая, М. М. Руда \\ гвуз «Тернопольский государственный медицинский университет имени И. Я. Горбачевского \\ МОЗ Украины»
}

РЕЗЮМЕ. Приведены результаты исследования показателей синдрома эндогенной интоксикации у больных ХОБЛ зрелого и среднего возраста при включении в комплексную терапию заболевания энтеросорбентов энтеросгель или карболайн. Отмечено положительное влияние энтеросорбции на фоне базисной терапии больных ХОБЛ, о чем свидетельствуют уменьшение уровня молекул средней массы и нормализация эритроцитарного индекса интоксикации.

КЛЮЧЕВЫЕ СЛОВА: ХОБЛ; энтеросгель; карболайн; синдром эндогенной интоксикации.

\section{EFFECTIVENESS OF THE USAGE OF ENTEROSORBENT THERAPY IN COMPLEX TREATMENT \\ OF PATIENTS WITH CHRONIC OBSTRUCTIVE PULMONARY DISEASE OF MATURE AND MIDDLE AGE WITH LABORATORY FEATURES OF ENDOGENOUS INTOXICATION}

@S. M. Andreychyn, S. V. Kucher, I. I. Hanberher, N. A. Kavetska, M. M. Ruda I. Horbachevsky Ternopil State Medical University

SUMMARY. The results of the study parameters of endogenous intoxication syndrome in patients with COPD mature and middle aged after including in the complex therapy of disease enterosorbents enterosgel or karbolayn. Enterosorption marked positive effect on the background of basic therapy of COPD patients, as evidenced was the reduction of middle mass molecules and normalization of erythrocyte index of intoxication.

KEY WORDS: COPD; enterosgel; karbolayn; syndrome of endogenous intoxication. 